\title{
Simultaneous Removal of Phenol and Ammonium Using Serratia sp. LJ-1 Capable of Heterotrophic Nitrification-Aerobic Denitrification
}

\author{
Jian Lu • Qiang Jin • Yiliang He • Xia He • Juan Zhao
}

Received: 2 June 2014 / Accepted: 8 August 2014 / Published online: 20 August 2014

(C) Springer International Publishing Switzerland 2014

\begin{abstract}
The simultaneous removal of phenol and ammonium using heterotrophic nitrifying-denitrifying bacterium Serratia sp. LJ-1 was investigated. The maximum removal rates of ammonium nitrogen and phenol were $1.08 \pm 0.05$ and $2.14 \pm 0.08 \mathrm{mg} \mathrm{L}^{-1} \mathrm{~h}^{-1}$, respectively. The ammonium oxidation had much higher tolerance to phenol toxicity than that of the autotrophic nitrifying bacteria. The increase in phenol concentration led to an increase in ammonium oxidation rate under the phenol concentration of $600 \mathrm{mg} \mathrm{L}^{-1}$. The increase in ammonium concentration caused an increase in phenol biodegradation rate under the ammonium nitrogen concentration of $150 \mathrm{mg} \mathrm{L}^{-1}$. Maximum rates of phenol biodegradation and total nitrogen removal in the treatments with nitrification metabolite (nitrate or nitrite) as the sole nitrogen source were more than $30 \%$ lower than those of the treatment with ammonium as the sole nitrogen source. Ammonium was removed through nitrification and subsequent aerobic
\end{abstract}

J. Lu $\cdot$ Q. Jin $\cdot$ Y. He $(\bowtie) \cdot X . H e \cdot J$. Zhao

School of Environmental Science and Engineering, Shanghai

Jiao Tong University,

Shanghai 200240, People's Republic of China

e-mail: ylhe@sjtu.edu.cn

J. Lu ( $ه)$

School of Civil and Environmental Engineering, Georgia Institute of Technology,

Atlanta, GA 30332, USA

e-mail: lujian.leonard@gatech.edu

X. He

Department of Civil and Environmental Engineering, University of Hawaii,

Honolulu, HI 96822, USA denitrification while phenol was biodegraded through the ortho-cleavage pathway and subsequently mineralized. Since phenol often coexists with nitrogen pollutants, these findings have significant environmental implications in terms of the simultaneous removal of these contaminants.

Keywords Phenol - Ammonium - Biodegradation .

Heterotrophic nitrification

\section{Introduction}

Hazardous aromatic organic pollutants often coexist with ammonium in wastewater (Amor et al. 2005). Among these organic toxicants, phenol is the most common (Liang and Ni 2009). Phenol is very toxic, with a fixed low admissible level of $0.5 \mathrm{mg} \mathrm{L}^{-1}$ in water (Polat et al. 2006; Girods et al. 2009). Ammonium ion $\left(\mathrm{NH}_{4}{ }^{+}\right)$is one of the important pollutants in municipal sewage and industrial wastewater because it can cause increased oxygen demand and eutrophication in rivers and lakes (Liang and Ni 2009). Therefore, the wastewater biological treatment requires the simultaneous removal of aromatic organic compounds and ammonium. Nitrification has been proven to be an effective method for ammonium removal (Rittmann and McCarty 2001). However, the nitrification process may be severely inhibited in the presence of phenol because phenol is a common nitrification inhibitor (Neufeld et al. 1980). A previous study showed that ammonium oxidation could be inhibited $75 \%$ by phenol at a concentration of $5.64 \mathrm{mg} \mathrm{L}^{-1}$ in sewage sludge (Staford 1974). 
Simultaneous removal of phenol and ammonium had been achieved in an activated sludge reactor by two successive steps, relying on the cooperation between autotrophic bacteria and heterotrophic bacteria which may subsequently lead to complicated bioreactor operation (Amor et al. 2005).

Nitrification and denitrification have been traditionally regarded as essentially separate phenomena, carried out by different bacteria in segregated areas of soils, sediments, water, or reactors (Kuenen and Robertson 1994). Recently, bacteria possessing abilities of heterotrophic nitrification and aerobic denitrification have been studied as potential microorganisms that may be used to overcome problems inherent in the conventional methods (Joo et al. 2005). Low molecular weight organic acids, glucose, and methanol are usually used as the carbon sources for these bacteria (Robertson et al. 1988; Arts et al. 1995). Little information is available on the nitrification and subsequent denitrification of bacteria with heterotrophic nitrification abilities in the presence of hazardous organic pollutants. Studies have shown that autotrophic ammonium oxidation bacteria such as Nitrosomonas europaea have the ability to simultaneously oxidize ammonium and phenol (Hyman et al. 1985; Shi et al. 2004). However, the phenol could only be partly oxidized (i.e., not mineralized), causing the accumulation of hydroquinone regarded as the dead-end metabolite (Hyman et al. 1985). Additionally, ammonium was only oxidized into nitrite $\left(\mathrm{NO}_{2}{ }^{-}\right)$or nitrate $\left(\mathrm{NO}_{3}{ }^{-}\right)$rather than removed as dinitrogen $\left(\mathrm{N}_{2}\right)$. There is no report on microorganisms with the ability to simultaneously remove phenol as carbon dioxide $\left(\mathrm{CO}_{2}\right)$ and ammonium as $\mathrm{N}_{2}$.

Our previous research showed that bacteria with heterotrophic nitrification ability can remove the ethoxylate groups of nonylphenol ethoxylates, suggesting that this kind of bacteria might have potential for the biodegradation removal of some hazardous organic pollutants ( $\mathrm{Lu}$ et al. 2008a). The removal of ammonium as $\mathrm{N}_{2}$ occurred simultaneously during the biodegradation of nonylphenol ethoxylates. In this study, the simultaneous removal of phenol and ammonium using Serratia sp. LJ-1 capable of heterotrophic nitrification-aerobic denitrification was investigated. The tolerance of nitrification on phenol toxicity was evaluated. The effect of ammonium concentration on the simultaneous removal of phenol and ammonium was investigated. The biodegradation pathway of phenol was also elucidated. The objective of this study was to obtain initial information on biodegradation of phenol and the simultaneous metabolism of ammonium by heterotrophic nitrifyingdenitrifying bacterium. Phenol was chosen as the model aromatic compound for this study since it was a typical aromatic pollutant of environmental interest. The finial goal was to determine the feasibility of the simultaneous removal of aromatic organic pollutants and nitrogen pollutants by taking advantage of heterotrophic nitrifier.

\section{Materials and Methods}

\subsection{Chemicals and Reagents}

High-performance liquid chromatography (HPLC)grade methanol was purchased from Tedia (Fairfield, OH, USA). Phenol, hydroquinone, catechol, 2hydroxymuconic semialdehyde (2-HMS), and cis, cismuconic acid were purchased from the Sigma-Aldrich Corporation (St. Louis, MO, USA). High-purity Milli-Q water was produced by a Milli-Q Plus system (Millipore, Billerica, MA, USA). All other reagents used were of reagent grade.

\subsection{Microorganism and Experimental Setup}

Heterotrophic nitrifier, Serratia sp. LJ-1 (GenBank access number EU137875) (Lu et al. 2008b) with simultaneous nitrification and denitrification ability, was isolated from a membrane bioreactor following previously reported methods (Lin et al. 2004). The red colonies of Serratia sp. LJ-1 grown on Luria-Bertani (LB) agar plate were transferred in LB medium with phenol (100 mg L ${ }^{-1}$ ) and cultivated at $30{ }^{\circ} \mathrm{C}$ and $120 \mathrm{rpm}$ on an orbital shaker in darkness. After 7 days $(168 \mathrm{~h})$, the cells were harvested by centrifugation at $4,000 \times g$ for $10 \mathrm{~min}$ and washed twice with $20 \mathrm{mM}$ potassium phosphate buffer solution $(\mathrm{pH}=7.0)$ before being used for wastewater treatment.

The incubations were performed in 500-mL flasks. One-hundred-milliliter synthetic wastewater containing phenol and ammonium was added into each flask. The cells of Serratia sp. LJ-1 were suspended in the wastewater at $1.0 \mathrm{~g} \mathrm{~L}^{-1}$ dry weight. Incubations were performed under room temperature $\left(30^{\circ} \mathrm{C}\right)$ on magnetic stirrers in darkness. All the treatments were performed in triplicate. The basic composition of the synthetic wastewater was as follows: $\mathrm{MgCl}_{2} \cdot 6 \mathrm{H}_{2} \mathrm{O}\left(0.1 \mathrm{~g} \mathrm{~L}^{-1}\right)$, $\mathrm{CaCl}_{2}\left(0.1 \mathrm{~g} \mathrm{~L}^{-1}\right), \mathrm{FeCl}_{2} \cdot 4 \mathrm{H}_{2} \mathrm{O}\left(0.01 \mathrm{~g} \mathrm{~L}^{-1}\right), \mathrm{K}_{2} \mathrm{HPO}_{4}$ $\left(0.27 \mathrm{~g} \mathrm{~L}^{-1}\right), \mathrm{KH}_{2} \mathrm{PO}_{4}\left(0.35 \mathrm{~g} \mathrm{~L}^{-1}\right)$, and $\mathrm{NaHCO}_{3}$ 
$\left(2.5 \mathrm{~g} \mathrm{~L}^{-1}\right)$. Ammonium was used as the nitrogen source while phenol was added as carbon source. Trace salts were also added into the medium according to Somsamak et al. (2001), and the $\mathrm{pH}$ was adjusted to 7 using $1 \mathrm{M} \mathrm{HCl}$.

\subsection{Experiments on the Simultaneous Removal of Phenol and Ammonium}

To investigate the simultaneous removal of phenol and ammonium during wastewater treatment, initial concentrations of ammonium nitrogen $\left(\mathrm{NH}_{4}{ }^{+}-\mathrm{N}\right)$ and phenol were 100 and $400 \mathrm{mg} \mathrm{L}^{-1}$, respectively. Evolution of ammonium metabolites during wastewater treatment was monitored. An uninoculated control (prepared with no additional inocula) and a heat-killed control (prepared by sterilizing the wastewater in an autoclave at $120{ }^{\circ} \mathrm{C}$ for $20 \mathrm{~min}$ ) were performed. To investigate the effect of different phenol concentrations on nitrification and phenol biodegradation, the initial concentrations of phenol were $0,15,30,60,150,300,400,600,1,000$, 1,500 , and $2,000 \mathrm{mg} \mathrm{L}^{-1}$. To determine the effect of different ammonium concentration on phenol removal and nitrification, the initial concentrations of $\mathrm{NH}_{4}{ }^{+}-\mathrm{N}$ were $50,100,150,500$, and $1,000 \mathrm{mg} \mathrm{L}^{-1}$.

\subsection{Phenol Biodegradation Assays with Different Nitrification Metabolites of Ammonium}

To evaluate the effect of typical nitrification metabolite of ammonium, the ammonium in the synthetic wastewater was replaced by nitrate or nitrite. Initial concentrations of nitrogen $\left(\mathrm{NH}_{4}{ }^{+}-\mathrm{N}, \mathrm{NO}_{2}{ }^{-}-\mathrm{N}, \mathrm{NO}_{3}{ }^{-}-\mathrm{N}\right)$ and phenol were 100 and $400 \mathrm{mg} \mathrm{L}^{-1}$, respectively. To obtain further evidence on the enhancement of nitrate or nitrite on phenol biodegradation, the control using the $\mathrm{NH}_{4}{ }^{+} \mathrm{N}$ as the sole nitrogen source was also included.

\subsection{Biodegradation Assays of Phenol and Its Metabolites}

To monitor the evolution of intermediates of phenol during wastewater treatment, concentrations of potential intermediates including catechol, hydroquinone, 2HMS, and cis, cis-muconic acid were monitored. To get more information on the phenol biodegradation, the biodegradation of two detected phenol biodegradation intermediates (catechol and cis, cis-muconic acid) of phenol was investigated. In these tests, phenol in the synthetic wastewater was replaced by catechol or cis, cis-muconic acid as the sole carbon source. Initial concentration of $\mathrm{NH}_{4}{ }^{+}-\mathrm{N}$ was $100 \mathrm{mg} \mathrm{L}^{-1}$ while those of phenol, catechol, and cis, cis-muconic acid were 400, 5 , and $5 \mathrm{mg} \mathrm{L}^{-1}$, respectively. Phenol biodegradation intermediates were spiked at low level based on their concentration levels in the phenol biodegradation experiment. All treatments had two controls, including an uninoculated control (prepared with no additional inocula) and a heat-killed control (prepared by sterilizing the wastewater in an autoclave at $120^{\circ} \mathrm{C}$ for $20 \mathrm{~min}$ ).

\subsection{Experiments on Carbon and Nitrogen Mass Balances}

To obtain further evidence on the simultaneous removal of phenol and ammonium by Serratia sp. LJ-1, experiments focusing on carbon and nitrogen mass balances were performed, following previous methods (Alva and Peyton 2003; Joo et al. 2005). Incubations were conducted in 1-L serum bottles sealed with rubber septa for $120 \mathrm{~h}$. The wastewater $(100 \mathrm{~mL})$ was flushed with highpurity oxygen for about $15 \mathrm{~min}$, and the headspace of the bottles was oxygen. Wastewater was added at low volume to ensure the oxygen was sufficient for the maintenance of aerobic conditions during the experiment. The carbon recovery refers to the percentage of sum of carbon contribution from inorganic carbon, cell carbon, and aqueous organic carbon to the total carbon (initial phenol carbon) (Alva and Peyton 2003). The inorganic carbon refers to the sum of carbon contribution from inorganic carbon in water and carbon dioxide in headspace. The nitrogen recovery refers to the percentage of sum of nitrogen contribution from final $\mathrm{NH}_{4}{ }^{+}-\mathrm{N}$, nitrification product nitrogen $\left(\mathrm{NO}_{2}{ }^{-}-\mathrm{N}\right.$, $\mathrm{NO}_{3}{ }^{-}-\mathrm{N}$, and hydroxylamine nitrogen $\left(\mathrm{NH}_{2} \mathrm{OH}-\mathrm{N}\right)$ ), cell nitrogen, and denitrification product nitrogen $\left(\mathrm{N}_{2}-\right.$ $\mathrm{N}$, nitrous oxide nitrogen $\left(\mathrm{N}_{2} \mathrm{O}-\mathrm{N}\right)$, and nitric oxide nitrogen (NO-N)) to the total input nitrogen (initial $\mathrm{NH}_{4}{ }^{+}-\mathrm{N}$ ) (Joo et al. 2005). The intracellular carbon and nitrogen contents were calculated from the dry cell weight by assuming biomass composition to be $\mathrm{C}_{5} \mathrm{H}_{7} \mathrm{O}_{2} \mathrm{~N}$ (Kim et al. 2005). Other forms of carbon and nitrogen were obtained through instrument analysis.

\subsection{Analytical Methods}

All aqueous samples were centrifuged for $15 \mathrm{~min}$ at $21,100 \times g$ before being subjected to subsequent analysis. 
Phenol and its metabolites were analyzed according to Costa et al. (1999) with slight modification. HPLC analysis was performed using a Hewlett-Packard Series 1100 HPLC (Agilent Technologies, Palo Alto, CA, USA) equipped with a diode array detector. The chromatographic separation was carried out in the reversed-phase mode with a Hypersil ODS column $(250 \mathrm{~mm} \times 4.6 \mathrm{~mm}$ i.d. particle packing size of $5 \mu \mathrm{m})$. The mobile phase used was a mixture of $5 \mathrm{mM} \mathrm{K}_{3} \mathrm{PO}_{4}(\mathrm{pH} 3.4$ with phosphoric acid)-methanol $(80: 20, v / v)$, and the flow rate was maintained at $1.0 \mathrm{~mL} \mathrm{~min}^{-1}$. Phenol, catechol, hydroquinone, cis, cis-muconic acid, and 2-HMS were determined by the comparison of the retention time and the UV/visible absorption spectra (200-800 nm). HPLC quantification was performed with an injection volume of $20 \mu \mathrm{L}$, and the column effluent was monitored at $270 \mathrm{~nm}$. The method limit of detections (LODs) of phenol, catechol, and hydroquinone were $0.1 \mathrm{mg} \mathrm{L}^{-1}$, while those of cis, cismuconic acid and 2-HMS were $0.5 \mathrm{mg} \mathrm{L}^{-1}$.

Ammonium was determined using a spectrophotometric method (APHA 1998), and $\mathrm{NH}_{2} \mathrm{OH}$ was measured according to Frear and Burrell (1955) using a UV/ visible spectrophotometer (UV-2450PC, Shimadzu, Japan). Concentrations of nitrate and nitrite $\left(\mathrm{NO}_{2}{ }^{-}\right)$were measured using a MIC ion chromatograph (Metohm, Switzerland). Inorganic carbon and total soluble nitrogen of the supernatant were measured simultaneously using a TOC-5050A total carbon analyzer (Shimadzu, Japan). Headspace samples of $\mathrm{N}_{2}, \mathrm{~N}_{2} \mathrm{O}, \mathrm{NO}$, and $\mathrm{CO}_{2}$ from the mass balance experiment were measured using a Hewlett-Packard 5890 series gas chromatograph (Agilent Technologies, Palo Alto, CA, USA) equipped with two separation columns and a thermal conductivity detector (TCD). Column 1 was a Porapack Q column (hp 19006C) used for the separation of $\mathrm{N}_{2} \mathrm{O}, \mathrm{CO}_{2}, \mathrm{H}_{2} \mathrm{O}$, and the mixture of $\mathrm{N}_{2}$ and $\mathrm{O}_{2}$. Column 2 was a Molsieve column (hp 19096A-010) used for the separation of $\mathrm{N}_{2}$ and $\mathrm{O}_{2}$ in the effluent of column 1 . The detector temperature was $200{ }^{\circ} \mathrm{C}$. Dissolved oxygen within the media was monitored with a Thermo Orion Model 830A DO meter (Thermo Orion, Beverly, MA, USA) to confirm maintenance of aerobic conditions. The maximum removal rates of $\mathrm{NH}_{4}{ }^{+}-\mathrm{N}$, total soluble nitrogen (TN), and phenol were determined following the previously described method (Lu et al. 2008c).

Biomass content in water samples was determined by measuring the optical density at $600 \mathrm{~nm}\left(\mathrm{OD}_{600}\right)$ using a spectrophotometer following previous method (Shim et al. 2005). A linear correlation between cell dry weight and $\mathrm{OD}_{600}$ was obtained, and one unit of $\mathrm{OD}_{600}$ was found to be equivalent to $0.31 \mathrm{~g}$ cell dry weight per liter. The maximum growth rate was determined using logistic growth model (Perni et al. 2005). Biomass production was calculated using difference between the biomass at the end the experiment and the biomass at the beginning the experiment.

\section{Results}

\subsection{Simultaneous Removal of Phenol and Ammonium}

Simultaneous removal of ammonium and phenol occurred when phenol was degraded by the heterotrophic nitrifying strain LJ-1 (Fig. 1). At the end of the experiments, more than $90 \%$ of both total soluble organic carbon and nitrogen were removed, indicating that phenol was mineralized while the ammonium was totally removed by strain LJ-1. The maximum removal rates of phenol and $\mathrm{NH}_{4}{ }^{+}-\mathrm{N}$ were $2.14 \pm 0.08$ and $1.08 \pm$ $0.05 \mathrm{mg} \mathrm{L}^{-1} \mathrm{~h}^{-1}$, respectively. Total soluble nitrogen was concomitantly removed. The maximal removal was $0.62 \pm 0.02 \mathrm{mg} \mathrm{L}^{-1} \mathrm{~h}^{-1}$, which was nearly $60 \%$ of the ammonium nitrogen removal rate. The nitrogen mass balance study (Table 1) showed that most of ammonium was recovered as $\mathrm{N}_{2}(54 \%)$, indicating that ammonium was removed as $\mathrm{N}_{2}$.

Changes in the concentration of ammonium, hydroxylamine, nitrite, and nitrate during the biodegradation period of phenol were also monitored to get further information for the effect of phenol on the heterotrophic nitrification pathway. The consumption of ammonium was concomitant with the removal of dissolved nitrogen. Hydroxylamine, nitrite, and nitrate were formed during this heterotrophic nitrogen removal process. Ammonium was firstly oxidized to hydroxylamine, which was rapidly oxidized into nitrite. The concentration of hydroxylamine reached its peak at $96 \mathrm{~h}$, much earlier than that of nitrate. Interestingly, there were two peaks in the concentration of nitrite. The formation of hydroxylamine and nitrite led to their accumulation from $72 \mathrm{~h}$. Nitrite was then oxidized into nitrate which led to the later accumulation of nitrate. The subsequent reduction of nitrate led to the second accumulation of nitrite.

The rapid growth and reproduction of strain LJ-1 confirmed the feasibility of using nitrifyingdenitrifying bacterium for the simultaneous removal of phenol and ammonium during wastewater treatment. 
Fig. 1 Simultaneous removal of phenol and ammonium and growth of Serratia sp. LJ-1 during incubation. The initial concentration of ammonium nitrogen $(\mathrm{N})$ was $100 \mathrm{mg} \mathrm{L}^{-1}$ while that of phenol was $400 \mathrm{mg} \mathrm{L}^{-1}$. Nitrite and nitrate were not detected in controls

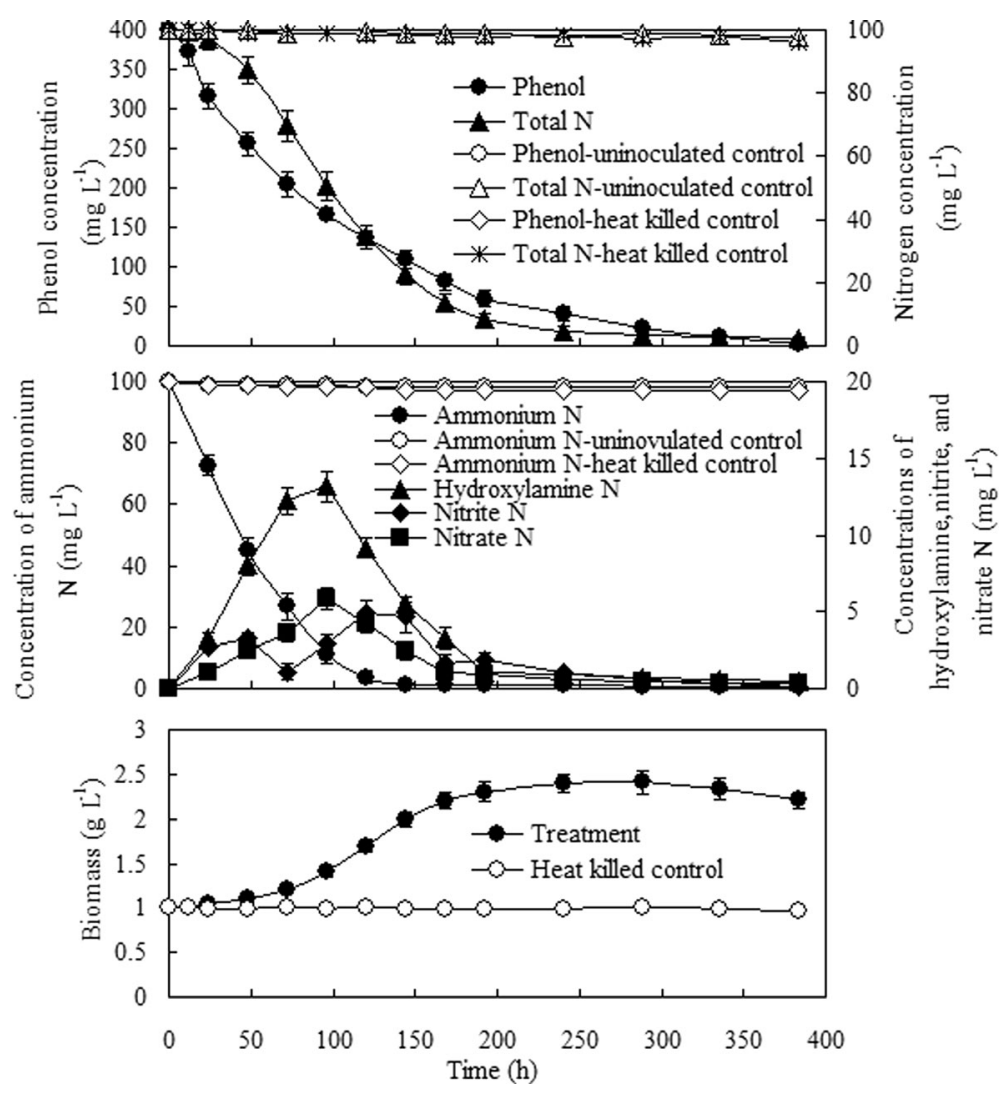

The bacterium grew rapidly with a short lag period, and the maximum biomass content $\left(2.42 \pm 0.10 \mathrm{~g} \mathrm{~L}^{-1}\right)$ was observed after 200-h incubation. The maximum growth rate was $12.5 \pm 0.2 \mathrm{mg} \mathrm{L}^{-1} \mathrm{~h}^{-1}$.

\subsection{Effect of Phenol Concentration on Ammonium Oxidization and Phenol Biodegradation}

The nitrification is usually sensitive to phenol (Staford 1974; Neufeld et al. 1980). To evaluate the tolerance of nitrification in heterotrophic nitrifier Serratia sp. LJ-1 to phenol toxicity, ammonium oxidation tests were performed under different phenol concentrations. The results showed that inhibition of ammonium oxidation by phenol occurred only at very high phenol concentrations (Fig. 2). The maximum oxidation rate of ammonium nitrogen $\left(1.38 \pm 0.23 \mathrm{mg} \mathrm{L}^{-1} \mathrm{~h}^{-1}\right)$ was reached when the initial concentration of phenol increased to $600 \mathrm{mg} \mathrm{L}^{-1}$ and almost ceased $\left(0.06 \pm 0.01 \mathrm{mg} \mathrm{L}^{-1} \mathrm{~h}^{-1}\right)$ when the phenol concentration increased to $1,500 \mathrm{mg} \mathrm{L}^{-1}$. At low phenol concentrations, the removal rates of ammonium and phenol increased in direct proportion to phenol concentration. The increase in phenol concentration led to a linear increase in the removal rates of both ammonium and phenol under the phenol concentration of $600 \mathrm{mg} \mathrm{L}^{-1}$. The ammonium oxidation rate increased from $0.04 \pm 0.00$ to $1.35 \pm 0.16 \mathrm{mg} \mathrm{L}^{-1} \mathrm{~h}^{-1}$ when the initial ammonium concentration increased from 15 to $600 \mathrm{mg} \mathrm{L}^{-1}$ while phenol removal rate increased from $0.12 \pm 0.01$ to $3.13 \pm 0.28 \mathrm{mg} \mathrm{L}^{-1} \mathrm{~h}^{-1}$.

3.3 Effect of Ammonium Concentration on Ammonium Oxidization and Phenol Biodegradation

The biodegradation rate of phenol and ammonium oxidation rate at different ammonium concentrations were measured to obtain further information on the relationship between heterotrophic nitrification and phenol biodegradation. At low ammonium concentrations, the increase in ammonium concentration caused the increase in both ammonium oxidation rate and phenol removal rate (Fig. 3). The phenol removal rate increased from $1.69 \pm$ 0.10 to $2.16 \pm 0.14 \mathrm{mg} \mathrm{L}^{-1} \mathrm{~h}^{-1}$ when the initial ammonium $\mathrm{N}$ concentration increased from 50 to $150 \mathrm{mg} \mathrm{L}^{-1}$ while the ammonium oxidation rate increased from 0.65 \pm 0.04 to $1.05 \pm 0.08 \mathrm{mg} \mathrm{L}^{-1} \mathrm{~h}^{-1}$. The phenol removal rate 
Table 1 Nitrogen balance of ammonium removal

\begin{tabular}{|c|c|c|c|c|}
\hline & & Treatment & Uninoculated control & Heat-killed control \\
\hline \multirow[t]{2}{*}{$\mathrm{NH}_{4}^{+}-\mathrm{N}(\mathrm{mg})$} & Initial $\mathrm{NH}_{4}^{+}-\mathrm{N}$ & 10.00 & 10.0 & 10.00 \\
\hline & Final $\mathrm{NH}_{4}{ }^{+}-\mathrm{N}$ & 0.08 & 10.0 & 9.94 \\
\hline \multirow[t]{3}{*}{ Nitrification products (mg) } & $\mathrm{NH}_{2} \mathrm{OH}-\mathrm{N}$ & 0.30 & 0 & 0 \\
\hline & $\mathrm{NO}_{2}^{-}-\mathrm{N}$ & 0.12 & 0 & 0 \\
\hline & $\mathrm{NO}_{3}{ }^{-}-\mathrm{N}$ & 0.18 & 0 & 0 \\
\hline Intracellular N (mg) & & 2.56 & 0 & 0 \\
\hline \multirow[t]{3}{*}{ Dinitrification products (mg) } & $\mathrm{N}_{2}-\mathrm{N}$ & 5.36 & 0 & 0 \\
\hline & $\mathrm{N}_{2} \mathrm{O}-\mathrm{N}$ & 0.36 & 0 & 0 \\
\hline & NO-N & 0 & 0 & 0 \\
\hline Nitrogen recovery $(\%)^{\mathrm{a}}$ & & 90 & 100 & 99 \\
\hline
\end{tabular}

The mass balance experiment was performed in sealed bottles containing $100 \mathrm{~mL}$ of wastewater. Initial concentrations of ammonium nitrogen $\left(\mathrm{NH}_{4}^{+}-\mathrm{N}\right)$ and phenol were 100 and $400 \mathrm{mg} \mathrm{L}^{-1}$, respectively

${ }^{\text {a }}$ The nitrogen recovery refers to the percentage of sum of nitrogen contribution from final $\mathrm{NH}_{4}{ }^{+}-\mathrm{N}$, nitrification product nitrogen $\left(\mathrm{NH}_{2} \mathrm{OH}-\right.$ $\mathrm{N}, \mathrm{NO}_{2}{ }^{-} \mathrm{N}$, and $\left.\mathrm{NO}_{3}{ }^{-}-\mathrm{N}\right)$, cell nitrogen, and denitrification product nitrogen $\left(\mathrm{N}_{2} \mathrm{O}-\mathrm{N}, \mathrm{NO}-\mathrm{N}, \mathrm{N}_{2}-\mathrm{N}\right)$ to the total input nitrogen (initial $\left.\mathrm{NH}_{4}^{+}-\mathrm{N}\right)$

began to decrease at relatively high $\mathrm{NH}_{4}{ }^{+}-\mathrm{N}$ concentrations $\left(>150 \mathrm{mg} \mathrm{L}^{-1}\right.$ ), indicating the occurrence of the inhibition on phenol biodegradation. Ammonium with high concentration could compete with phenol for the same electron acceptor (oxygen), which subsequently led to the substrate inhibition of phenol biodegradation.

\subsection{Effects of Nitrification Metabolites on the Phenol Biodegradation and Nitrogen Removal}

The effects of nitrification metabolites including nitrite and nitrate on phenol biodegradation were investigated to get further information on the influence of nitrification process on phenol biodegradation (Table 2). The results showed that the phenol removal rate was $1.21 \pm$ $0.05 \mathrm{mg} \mathrm{L}^{-1} \mathrm{~h}^{-1}$ when nitrite was added as the sole nitrogen source while that of the nitrate treatment was $1.39 \pm 0.05 \mathrm{mg} \mathrm{L}^{-1} \mathrm{~h}^{-1}$. Total nitrogen removal rate was $0.40 \pm 0.04 \mathrm{mg} \mathrm{L}^{-1} \mathrm{~h}^{-1}$ when nitrite was added as the sole nitrogen source while that of the nitrate treatment was $0.44 \pm 0.03 \mathrm{mg} \mathrm{L}^{-1} \mathrm{~h}^{-1}$. Compared with the ammonium treatment, both the phenol biodegradation rates and nitrogen removal rates in the presence of nitrite and nitrate were relatively low.

\subsection{Phenol Biodegradation Pathway}

To determine the biodegradation pathway of phenol by strain LJ-1, the evolution of typical metabolites during phenol biodegradation was monitored (Fig. 4). The results showed that two typical intermediates (catechol and cis, cis-muconic acid) (Parke et al. 2000; Alva and Peyton 2003) were detected. The rapid biodegradation of phenol led to the accumulation of catechol which reached its concentration peak at $96 \mathrm{~h}$. The catechol appeared transiently and was later degraded. The subsequent removal of catechol was followed with the accumulation of cis, cis-muconic acid which reached its concentration peak at $168 \mathrm{~h}$. Additionally, both of two

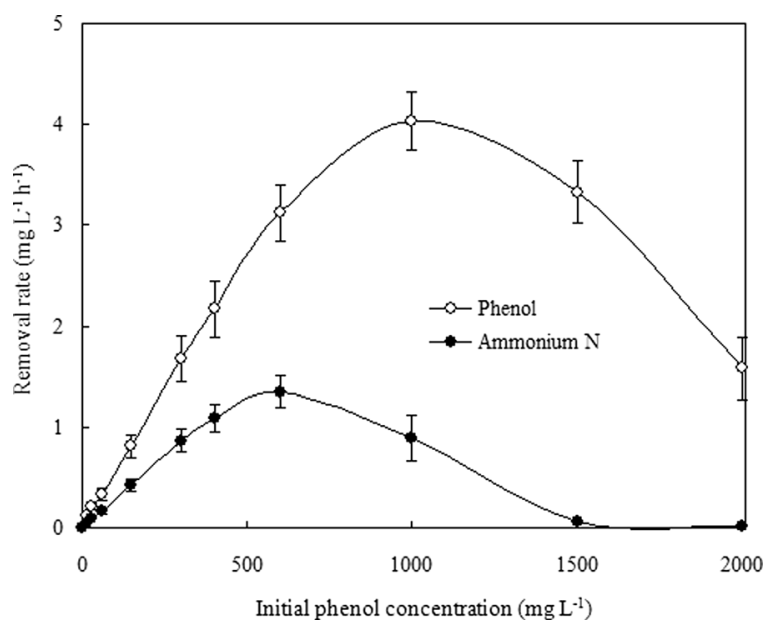

Fig. 2 Effect of phenol concentration on ammonium oxidization and phenol biodegradation. The initial concentration of ammonium nitrogen $(\mathrm{N})$ was $100 \mathrm{mg} \mathrm{L}^{-1}$. Initial concentrations of phenol were $0,15,30,60,150,300,400,600,1,000,1,500$, and $2,000 \mathrm{mg} \mathrm{L}^{-1}$ 


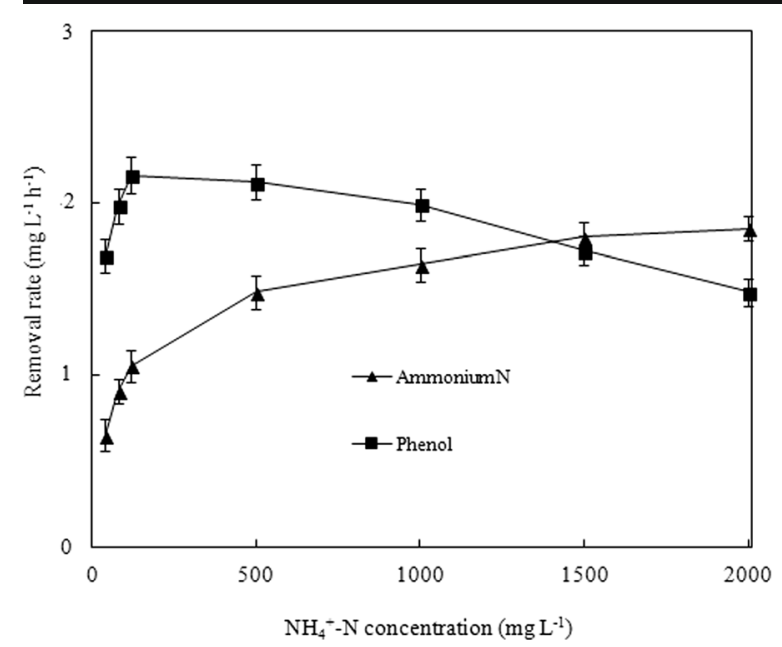

Fig. 3 Effect of ammonium concentration on ammonium oxidization and phenol biodegradation. The initial concentration of phenol was $400 \mathrm{mg} \mathrm{L}^{-1}$. Initial concentrations of ammonium nitrogen $(\mathrm{N})$ were $50,100,150,500,1,000,1,500$, and $2,000 \mathrm{mg} \mathrm{L}^{-1}$

typical intermediates (catechol and cis, cis-muconic acid) were removed rapidly when they were used as the sole carbon source. The carbon mass balance experiment showed that the fate of phenol carbon in terms of inorganic carbon, cell carbon, metabolites (catechol and cis, cis-muconic acid), and residual phenol gave high carbon recovery of $87 \%$ (Table 3). Among all the phenol carbon, inorganic carbon contributed $50 \%$, indicating the high degree of phenol mineralization during biodegradation.

\section{Discussion}

The simultaneous removal of phenol and ammonium usually relies on the cooperation between autotrophic bacteria and heterotrophic bacteria which may

Table 2 Effects of nitrification metabolite on the removal of phenol and total nitrogen

\begin{tabular}{lll}
\hline & $\begin{array}{l}\text { Removal rate of } \\
\text { phenol }\left(\mathrm{mg} \mathrm{L}^{-1} \mathrm{~h}^{-1}\right)\end{array}$ & $\begin{array}{l}\text { Removal rate of total } \\
\text { nitrogen }\left(\mathrm{mg} \mathrm{L}^{-1} \mathrm{~h}^{-1}\right)\end{array}$ \\
\hline Nitrate $\mathrm{N}$ & $1.39 \pm 0.05$ & $0.44 \pm 0.03$ \\
Nitrite $\mathrm{N}$ & $1.21 \pm 0.05$ & $0.40 \pm 0.04$ \\
Ammonium & $2.13 \pm 0.10$ & $0.64 \pm 0.03$ \\
$\mathrm{~N}$ (control) & &
\end{tabular}

Initial concentrations of nitrogen (ammonium $\mathrm{N}$, nitrite $\mathrm{N}$, or nitrate $\mathrm{N}$ ) and phenol were 100 and $400 \mathrm{mg} \mathrm{L}^{-1}$, respectively subsequently lead to complicated bioreactor operation (Amor et al. 2005). To our knowledge, this is the first report of the simultaneous removal of phenol and ammonium by heterotrophic nitrifying-denitrifying bacterium, which can biodegrade phenol and remove ammonium through the heterotrophic nitrification-aerobic denitrification. The maximum removal rates of phenol and $\mathrm{NH}_{4}{ }^{+}-\mathrm{N}$ in this study are similar to the previous report on activated sludge process with nitrification function (Amor et al. 2005), indicating considerable removal ability for phenol and ammonium by strain LJ-1. The nitrogen mass balance study showed that most of ammonium was recovered as $\mathrm{N}_{2}(54 \%)$, indicating that ammonium was removed as $\mathrm{N}_{2}$. In the presence of heterotrophic nitrifier LJ-1, ammonium was transformed into $\mathrm{N}_{2}$ and removed from the aqueous phase through nitrification-aerobic-dinitrification process. In the presence of heterotrophic nitrifiers, ammonium can be transformed into $\mathrm{N}_{2}$ and removed from the aqueous phase through nitrification-aerobic-dinitrification process (Joo et al. 2005). Evolution of ammonium, hydroxylamine, nitrite, and nitrate during the biodegradation period of phenol showed that the nitrification pathway was similar to that in both the heterotrophic nitrifiers (Joo et al. 2005; Lu et al. 2008a) and the autotrophic nitrifier (Rittmann and McCarty 2001), indicating that phenol had no effect on the nitrification pathway.

The ammonium oxidation using heterotrophic nitrification bacterium had good tolerance to phenol toxicity, suggesting the advantage of using heterotrophic nitrifying bacterium for the simultaneous removal of phenol and ammonium. The nitrification process is usually sensitive to organic toxicants such as phenol (Staford 1974; Neufeld et al. 1980), which leads to the challenge for the simultaneous removal of phenol and ammonium. Previous studies showed that ammonium oxidation by autotrophic nitrification bacteria could be easily inhibited at phenol concentrations as low as $5.64 \mathrm{mg} \mathrm{L}^{-1}$ (Staford 1974; Neufeld et al. 1980). Phenol removal rate kept increasing with the increase in phenol concentration at relatively high phenol concentrations $\left(>600 \mathrm{mg} \mathrm{L}^{-1}\right)$ when the ammonium oxidation began to be inhibited, indicating relatively high phenol biodegradation potential in the presence of heterotrophic nitrifying bacterium.

Phenol is necessary for ammonium removal since ammonium removal did not occur in the absence of organic carbon (phenol), confirming that the ammonium oxidization was catalyzed by heterotrophic but not autotrophic nitrifier. At low phenol concentrations, the 
Fig. 4 Changes of the concentrations of phenol, catechol, and cis, cis-muconic acid profiles in the biodegradation assays of phenol (a), catechol (b), and cis, cis-muconic acid (c). The initial concentration of ammonium $\mathrm{N}$ in all the biodegradation experiments was $100 \mathrm{mg} \mathrm{L}^{-1}$. Initial concentration of phenol was $400 \mathrm{mg} \mathrm{L}^{-1}$ in phenol biodegradation experiment. Initial concentrations of catechol and cis, cis-muconic acid were $5 \mathrm{mg} \mathrm{L}^{-1}$ in catechol and cis, cis-muconic acid biodegradation experiment, respectively
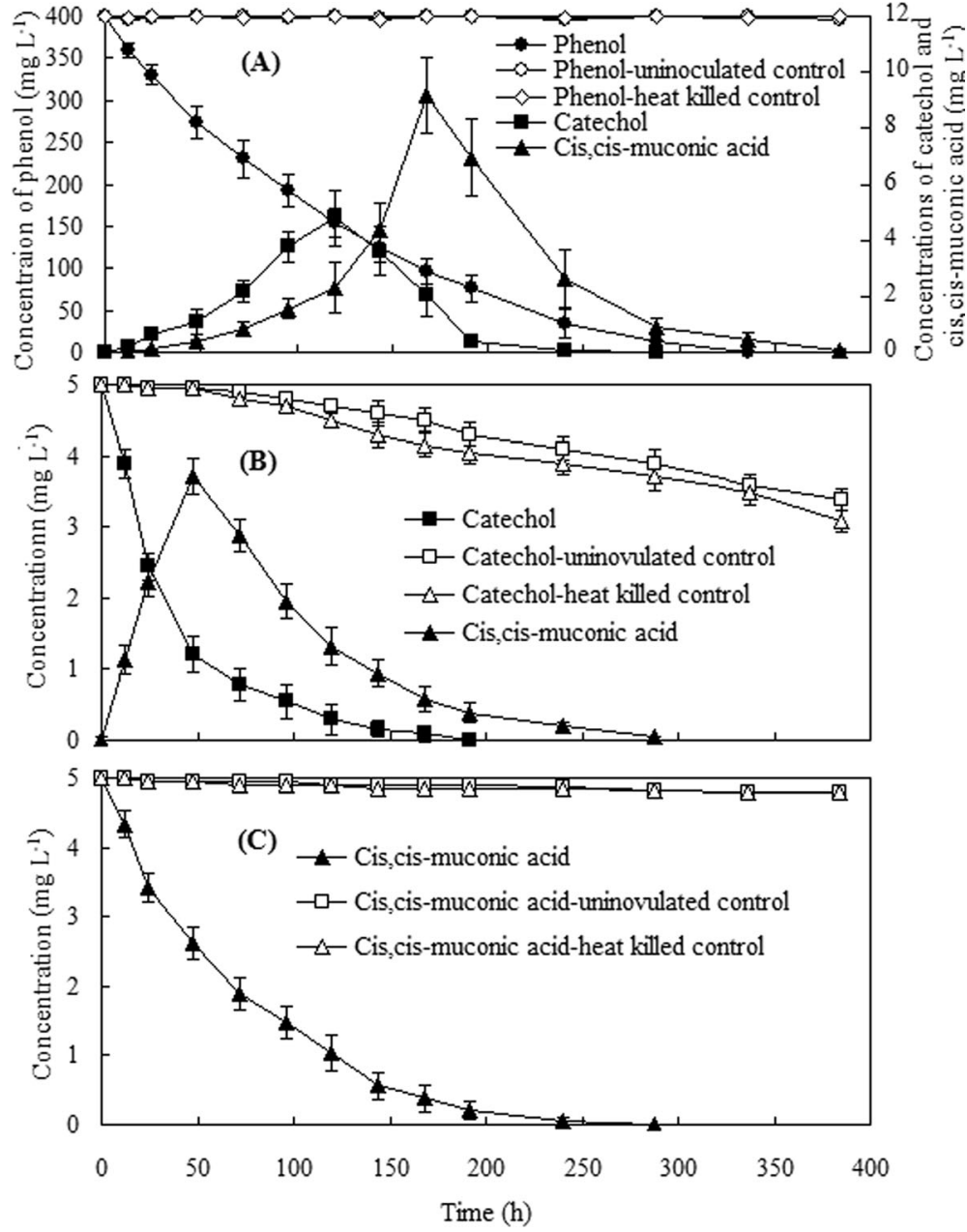

removal rates of ammonium increased in direct proportion to phenol concentration. The reasonable explanation for this phenomenon is that the oxidation of phenol can provide energy and carbon for the heterotrophic nitrifier strain LJ-1, which can subsequently promote the oxidation of ammonium. According to previous studies (Verstraete and Focht 1977; Castignetti and Hollocher 1982), heterotrophic nitrifiers are distinct from autotrophic nitrifiers, which use energy gained solely from the oxidation of inorganic nitrogen compounds. They oxidize reduced nitrogenous compounds and utilize organic carbon as carbon and energy sources.

$\mathrm{NH}_{4}{ }^{+}-\mathrm{N}$ is the preferable $\mathrm{N}$ source for strain $\mathrm{LJ}-1$ due to its heterotrophic nitrification ability. Maximum rates of phenol biodegradation and total nitrogen removal in the treatments with nitrate or nitrite as the sole nitrogen source were more than $30 \%$ lower than those of the treatment with $\mathrm{NH}_{4}{ }^{+}-\mathrm{N}$ as the sole nitrogen source. The presence of the ammonium could bring additional energy besides phenol oxidation for strain LJ-1 through nitrification process, which subsequently enhanced the ammonium oxidation and phenol biodegradation. For this reason, the treatment with ammonium as the nitrogen source had the highest removal rates of phenol and nitrogen pollutants. Since heterotrophic nitrifiers could use energy gained from the oxidation of both inorganic nitrogen compounds and organic carbon (Verstraete and Focht 1977; Castignetti and Hollocher 1982), the oxidation of ammonium could also provide energy for the heterotrophic nitrifier strain LJ-1, which could subsequently promote the oxidation of phenol. The increase in ammonium concentration caused the increase in phenol removal rate.

Catechol but not hydroquinone was detected when phenol was rapidly degraded, suggesting that ortho-tohydroxy attack by one oxygen atom occurred and led to 
Table 3 Carbon balance of phenol biodegradation

\begin{tabular}{clll}
\hline & Treatment & $\begin{array}{l}\text { Uninoculated } \\
\text { control }\end{array}$ & $\begin{array}{l}\text { Heat-killed } \\
\text { control }\end{array}$ \\
\hline Phenol carbon (mg) & & & \\
Initial phenol carbon & 30.64 & 30.64 & 30.64 \\
Final phenol carbon & 1.15 & 30.70 & 30.28 \\
Catechol carbon (mg) & 0.77 & 0 & 0 \\
cis, cis-Muconic acid & 2.53 & 0 & 0 \\
carbon (mg) & & 0 & 0 \\
Inorganic carbon (mg) & 15.40 & 0 & 0 \\
Cell carbon (mg) & 6.66 & 0 & 99 \\
Carbon recovery (\%) & 87 & 100 & \\
\hline
\end{tabular}

The mass balance experiment was performed in sealed bottles containing $100 \mathrm{~mL}$ of wastewater. Initial concentrations of ammonium nitrogen and phenol were 100 and $400 \mathrm{mg} \mathrm{L}^{-1}$, respectively

${ }^{\mathrm{a}}$ The inorganic carbon refers to the sum of carbon contribution from inorganic carbon in water and carbon dioxide in headspace

${ }^{b}$ The carbon recovery refers to the percentage of sum of carbon contribution from inorganic carbon, cell carbon, final phenol carbon, and metabolite carbon to the total carbon (initial phenol carbon)

the formation of catechol. Catechol is usually formed in the primary step of the phenol oxidation process in heterotrophic bacteria, while hydroquinone is formed in autotrophic nitrifying bacteria (Hyman et al. 1985). Phenol is usually oxidized into catechol, and then the ring of catechol is further cleaved by two known pathways, namely, the ortho-cleavage pathway, through which catechol is metabolized into cis, cis-muconic acid, and meta-cleavage pathway, through which catechol is transformed into 2-HMS (Parke et al. 2000; Alva and Peyton 2003). In this experiment, catechol appeared transiently and was later degraded. The removal of catechol was followed with the accumulation of cis, cis-muconic acid, a metabolite of the ortho-cleavage pathway, while the central metabolite in the meta-cleavage pathway (2-HMS) was not detected, suggesting that phenol was biodegraded through the ortho-cleavage pathway. Additionally, both of two typical intermediates (catechol and cis, cis-muconic acid) of phenol orthocleavage pathway could be degraded rapidly when they were used as the sole carbon source, confirming that phenol was biodegraded through the ortho-cleavage pathway. In the carbon mass balance experiment, the fate of phenol carbon in terms of inorganic carbon, cell carbon, metabolites, and residual phenol gave high carbon recovery, indicating reasonability for the assumed phenol biodegradation pathway. Moreover, high inorganic carbon recovery (50\%) showed the high degree of phenol mineralization during biodegradation. The ring structure often contributes to the toxicity and persistence of aromatic compounds, which makes ring cleavage the most important step in the biodegradation process of the aromatic compounds (Bouchez et al. 1996; Parke et al. 2000; Alva and Peyton 2003). The ring cleavage ability of heterotrophic nitrifying strain LJ-1 suggests that this heterotrophic nitrification bacterium has the potential advantage of phenol mineralization.

\section{Conclusion}

In this study, simultaneous removal of phenol and ammonium using heterotrophic nitrifying-denitrifying bacterium Serratia sp. LJ-1 was firstly investigated. The removal rates of both contaminants were notable. Phenol was degraded through the ortho-cleavage pathway before being mineralized while ammonium was removed as $\mathrm{N}_{2}$ through nitrification and subsequent aerobic denitrification. Phenol and ammonium could promote their removal efficiencies with each other at relatively low concentrations. The ammonium oxidation had much higher tolerance to phenol toxicity than that of the autotrophic nitrifier. The treatment with ammonium but not nitrification metabolites as the nitrogen source had the highest removal rates of phenol and nitrogen pollutants. Since phenol often coexists with nitrogen contaminants, these findings have significant environmental implications in terms of the simultaneous removal of these contaminants.

Acknowledgments This work is financially supported by the National Foundation of Science of China (Grant No. 50478019), and National Science and Technology Majoy Projects of Water Pollution Control and Management of China (2014ZX07206001). The authors would like to thank the anonymous reviewers for their reading of the manuscript and for their suggestions and critical comments.

\section{References}

Alva, V. A., \& Peyton, B. M. (2003). Phenol and catechol biodegradation by the haloalkaliphile Halomonas campisalis: influence of $\mathrm{pH}$ and salinity. Environmental Science \& Technology, 37, 4397-4402.

Amor, L., Eiroa, M., Kennes, C., \& Veiga, M. C. (2005). Phenolbiodegradation and its effect on the nitrification process. Water Research, 39, 2915-2920. 
APHA (American Public Health Association). (1998). Standard Methods for the Examination of Water and Wastewater (20th ed., Vol. 20). Washington, DC: APHA.

Arts, P. A. M., Robertson, L. A., \& Kuenen, J. G. (1995). Nitrification and denitrification by Thiosphaera pantotropha in aerobic chemostat cultures. FEMS Microbiology Ecology, 18, 305-316.

Bouchez, M., Blanchet, D., \& Vandecasteele, J. P. (1996). The microbiological fate of polycyclic aromatic hydrocarbons: carbon and oxygen balances for bacterial degradation of model compounds. Applied Microbiology and Biotechnology, 45, 556-561.

Castignetti, D., \& Hollocher, T. C. (1982). Nitrogen redox metabolism of a heterotrophic, nitrifying-denitrifying Alcaligenes sp. from soil. Applied and Environmental Microbiology, 44, 923-928.

Costa, C., Pupo, C., Viscomi, G., Catania, S., Salemi, M., \& Imperatore, C. (1999). Modifications in the metabolic pathways of benzene in streptozotocin-induced diabetic rat. Archives of Toxicology, 73, 301-306.

Frear, D. S., \& Burrell, R. C. (1955). Spectrophotometric method for determining hydroxylamine reductase activity in higher plants. Analytical Chemistry, 27, 1664-1665.

Girods, P., Dufour, A., Fierro, V., Rogaume, Y., Rogaume, C., Zoulalian, A., \& Celzard, A. (2009). Activated carbons prepared from wood particleboard wastes: characterisation and phenol adsorption capacities. Journal of Hazardous Materials, 166, 491-501.

Hyman, M. R., Sansome-Smith, A. W., Shears, J. H., \& Wood, P. M. (1985). A kinetic study of benzene oxidation to phenol by whole cells of Nitrosomonas europaea and evidence for the further oxidation of phenol to hydroquinone. Archives of Microbiology, 143, 302-306.

Joo, H. S., Hirai, M., \& Shoda, M. (2005). Characteristics of ammonium removal by heterotrophic nitrification-aerobic denitrification by Alcaligenes faecalis No.4. Journal of Bioscience and Bioengineering, 100, 184-191.

Kim, J. K., Park, K. J., Cho, K. S., Nam, S. W., Park, T. J., \& Bajpai, R. (2005). Aerobic nitrification-denitrification by heterotrophic Bacillus strains. Bioresource Technology, 96, 1897-1906.

Kuenen, J. G., \& Robertson, L. A. (1994). Combined nitrificationdenitrification processes. FEMS Microbiology Reviews, 15, 109-117.

Liang, Z., \& Ni, J. (2009). Improving the ammonium uptake onto natural zeolite by using an integrated modification process. Journal of Hazardous Materials, 166, 52-60.

Lin, Y., Kong, H., He, Y., Kuai, L., \& Inamori, Y. (2004). Simultaneous nitrification and denitrification in a membrane bioreactor and isolation of heterotrophic nitrifying bacteria. Japanese Journal of Water Treatment Biology, 40, 105-114.

Lu, J., Jin, Q., He, Y., Wu, J., \& Zhao, J. (2008a). Biodegradation of nonylphenol ethoxylates by Bacillus sp. LY capable of heterotrophic nitrification. FEMS Microbiology Letters, 280, 28-33.

Lu, J., Jin, Q., He, Y., Zhao, J., Wu, J. (2008b). Isolation and characterization of novel Serratia sp. LJ-1 for nonylphenol degradation. Unpublished GenBank entry EU137875.

Lu, J., Jin, Q., He, Y., Wu, J., Zhang, W., \& Zhao, J. (2008c). Biodegradation of nonylphenol polyethoxylates by denitrifying activated sludge. Water Research, 42, 1075-1082.

Neufeld, R. D., Hill, A. J., \& Adekoya, D. O. (1980). Phenol and free ammonia inhibition to Nitrosomonas activity. Water Research, 14, 1695-1703.

Parke, D., D’Argenio, D. A., \& Ornston, L. N. (2000). Bacteria are not what they eat: that is why they are so diverse. Journal of Bacteriology, 182, 257-263.

Perni, S., Andrew, P. W., \& Shama, G. (2005). Estimating the maximum growth rate from microbial growth curves: definition is everything. Food Microbiology, 22, 491-495.

Polat, H., Molva, M., \& Polat, M. (2006). Capacity and mechanism of phenol adsorption on lignite. International Journal of Mineral Processing, 79, 264-273.

Rittmann, B. E., \& McCarty, P. L. (2001). Environmental biotechnology: principles and applications (2nd ed.). New York: McGraw-Hill.

Robertson, L. A., Van Niel, E. W. J., Torremans, R. A. M., \& Kuenen, J. G. (1988). Simultaneous nitrification and denitrification in aerobic chemostat cultures of Thiosphaera pantotropha. Applied and Environmental Microbiology, 54, 2812-2818.

Shi, J., Fujisawa, S., Nakai, S., \& Hosomi, M. (2004). Biodegradation of natural and synthetic estrogens by nitrifying activated sludge and ammonia-oxidizing bacterium Nitrosomonas europaea. Water Research, 38, 2323-2330.

Shim, H., Hwang, B., Lee, S. S., \& Kong, S. H. (2005). Kinetics of BTEX biodegradation by a coculture of Pseudomonas putida and Pseudomonas fluorescens under hydroxic conditions. Biodegradation, 16, 319-327.

Somsamak, P., Cowan, R., \& Häggblom, M. M. (2001). Anaerobic biotransformation of fuel oxygenates under sulfate-reducing conditions. FEMS Microbiology Ecology, 37, 259-264.

Staford, D. A. (1974). The effect of phenol and heterocyclic bases on nitrification in activated sludges. Journal of Applied Bacteriology, 37, 75-82.

Verstraete, W., \& Focht, D. D. (1977). Biochemical ecology of nitrification and denitrification. Advances in Microbial Ecology, 1, 135-214. 